IN DEFENSE OF SOCIETY: THE INVENTION OF PALLIATIVE CARE AND SAFETY DEVICES ${ }^{1}$

\author{
Karen Schein da Silva², Maria Henriqueta Luce Kruse ${ }^{3}$
}

${ }^{1}$ This paper is part of a study called - In defense of society: the invention of palliative care, concluded in 2010 at Federal University of Rio Grande do Sul (UFRGS).

${ }^{2}$ M.Sc. in Nursing. Nurse, Medical Nursing Service, Clinics Hospital of Porto Alegre. Rio Grande do Sul, Brazil. E-mail: karen. schein@gmail.com

${ }^{3}$ Ph.D. in Education. Associate Professor, School of Nursing, UFRGS. Rio Grande do Sul. Brazil. E-mail: kruse@uol.com.br

\begin{abstract}
The article proposes thinking the corpus of knowledge on palliative care as an invention that would work as one of the tactics inserted in a bio-political strategy constituted in order to defend society. For the articulation of this discussion, the 2007 edition of the palliative care manual was used, published by the World Health Organization. Starting from the textual analysis of the discourse in the manual, with the help of the reference framework of cultural studies and inspired on the works by Michel Foucault, the study articulates one of the possible readings of the guide. Based on the crossing between material information and statements, one observes the re(organization) and (re)invention of a discipline that invests in the subjectivity of individuals, constituting apparatuses of truth in the intent to defend living.
\end{abstract}

DESCRIPTORS: Health policy. Palliative care. Education. Government. Nursing.

\title{
EM DEFESA DA SOCIEDADE: A INVENÇÃO DOS CUIDADOS PALIATIVOS E OS DISPOSITIVOS DE SEGURANÇA
}

RESUMO: O artigo propõe pensar o corpo de conhecimentos dos cuidados paliativos como uma invenção, que funcionaria como uma das táticas inseridas em uma estratégia biopolítica constituída para defender a sociedade. Para articular tal discussão, utilizamos o manual de cuidados paliativos, publicado no ano de 2007 pela Organização Mundial da Saúde. A partir da análise textual do discurso instituído pelo manual, com o auxílio do referencial dos Estudos Culturais e sob a inspiração dos escritos de Michel Foucault, articulamos uma das possíveis leituras do guia. A partir do entrecruzamento de materialidades e enunciados, observa-se a (re)organização e a (re) invenção de uma disciplina que investe na subjetividade dos indivíduos constituindo aparatos de verdade pretendendo defender a vida. DESCRITORES: Política de saúde. Cuidados paliativos. Educação. Governo. Enfermagem.

\section{EN DEFENSA DE LA SOCIEDAD: LA INVENCIÓN DE LOS CUIDADOS PALIATIVOS Y LOS DISPOSITIVOS DE SEGURIDAD}

\begin{abstract}
RESUMEN: El artículo propone pensar el corpus de conocimientos de los cuidados paliativos como una invención, que funcionaría como una de las tácticas inseridas en una estrategia bio-política constituida para defender la sociedad. Para articular tal discusión se utilizó el manual de cuidados paliativos, publicado el año 2007, por la Organización Mundial de la Salud. A partir del análisis textual del discurso instituido por el manual, con el auxilio del referencial de los estudios culturales e con inspiración en los escritos de Michel Foucault, se articuló una de las posibles lecturas del guía. A partir del cruzamiento de materialidades y enunciados se pasó a observar la (re)organización y la (re)invención de una disciplina que invierte en la subjetividad de los individuos constituyendo aparatos de verdad intentando defender la vida.
\end{abstract}

DESCRIPTORES: Política de salud. Cuidados paliativos. Educación. Gobierno. Enfermería. 


\section{THE BIRTH OF BIOPOLITICS}

What do we need to defend ourselves from? Or, better, have you ever stopped to consider what we are afraid of? Fear is a term that is difficult to defend and provokes some degree of discomfort but, if we had to say something about fear, that probably would not be simple. "Fear is how we name our uncertainty: our ignorance of the threat and of what has to be done" ${ }^{1: 8}$ Our society tries to turn life with fear into something tolerable, as "elimination is an avoidable destiny. It is like death, which you can try to keep at a distance for some time, but nothing you do will be able to stop it when the time has come". ${ }^{1: 38}$

I believe that simply asking what we are afraid of would not justify the title of this work; one needs to go beyond and, who knows, ask: what threatens us as a species? What threatens our existence? Death does not only cause fear, it is also a threat to life. We do not defend ourselves from the fear of death, but from the threat of dying. That is some of what we intend to discuss here. That was the start of the study: considering death as a threat to life, as a threat to the human species. This gave rise to many of the concerns and thoughts about the emergence of palliative care as a scientific discipline, destined to occupy certain spaces and articulate with other knowledge about death and dying. Thus, we intend to look at palliative care as an invented body of knowledge.

How is an invention made feasible? In general, the invention emerges from a feeling of wellbeing that may be established. This gives rise to motivations for the inventions: it is based on this discomfort, on the need for alternatives, that we are able to obtain the strength to mobilize and permit inventing something. To put this invention in practice, it needs to gain a value, a status, get disseminated, be socially accepted, creating a precedent for certain subjectivities and imposing new rules for the game of social functioning. ${ }^{2}$ We can look at the inventions, more specifically at the discourse regimens, as a production resulting from a series of events. Hence, to study them, we should look at the irruption, at the emergence of the new category. ${ }^{3}$
The event could be understood as a tool to understand the historical novelties, with a relation among the appearance, formation and functioning of practices. ${ }^{4}$

When we read any literature considered as scientific, we soon attempt to find out: who is the author? Who is entitled to pronounce those words? Who invented that? The principles of authorship serve to control and register the truths produced and grant power to those who pronounce a certain discourse. ${ }^{5}$ Thus, one might ask: who invented palliative care? What we intend to do is not to answer that question, but to think about the invented nature of this body of knowledge. We intend to look at palliative care as one of the artifacts that is part of a biopolitical device, which was invented in defense of society, as "it is interesting and productive to ask and examine how things work and happen and try out alternatives for them to function and happen in other ways" . ${ }^{6: 19}$ Hence, palliative care emerges as an alternative proposed to consider care delivery to patients who are beyond the stage of therapeutic possibilities of care in another manner, inventing another form of care.

The aim in this study is to look at the discourse disseminated in the palliative care manual the World Health Organization (WHO) published in 2007, so as to think of the body of palliative care knowledge as an invention, which would serve as one of the tactics in a bio-political strategy that was constituted to defend society. Therefore, we raise some inquiries: what statements does the manual use to organize and legitimize the body of palliative care knowledge? How are the "truths" about this discipline produced and how do they organize, disseminate and control this knowledge? How is this discourse articulated and how does it invent a "new" discipline, producing another rationality, building devices of truth ${ }^{* *}$, which subjectify us and also govern in defense of life?

Hence, studying part of the discursive formation of palliative care in the WHO manual allows us to observe how this knowledge circulates, the alliances it makes and how it captures the subjects and constitutes what we might call an invention of modern times.

\footnotetext{
* The titles of the sections in this study allude to the titles of the courses Michel Foucault taught at the Collège de France between 1970 and 1982.

** We consider truth as a set of rules according to which the truth is considered from the false and specific effects of power are attributed to the truth. ${ }^{7}$
} 


\section{THE THEORY AND ESTABLISHMENT OF KNOWLEDGE}

When investigating the metaphors involving cancer, we are generally confronted with the conceptions of this disease as a cruel and secret invader, which is untreatable, ruthless and acts slowly and treacherously. Even if the cancer does not always degenerate the body, causes pain or provokes death, this form of characterizing the disease is very widespread. Consequently, the equation that equals cancer and death remains highly prevalent. ${ }^{8}$

Considering death not only as a biological process, but also as a historical/cultural process, reveals that the way we face it is related to how certain discourses started to manage them. ${ }^{9}$

The technical and scientific knowledge before the $20^{\text {th }}$ century characterized medicine as predominantly palliative, focused or relieving suffering and treatments to improve the quality of life. ${ }^{2}$ Technological development in health, which became more intense as from the middle of the past century, turned individuals into healthcare consumers, producing certain ways of giving care that were no longer just aimed at relieving suffering, but also at curing illnesses. Hence, as a result of technology use and medical interventionism in hospital institutions, diseases started to be medicalized and medicine got fascinated by the possibility of extending and controlling life, while postponing death. ${ }^{2}$

The discussions about the problems related to death in the hospital context gained strength and became more frequent as from the end of the 1990's, when discourse about a "new" care modality, which emerged as a reaction to technical medicine, found their way, composing a knowledge that intended to establish death within another discourse regimen: palliative care. Then, a modification starts to take place in the formation of statements about death and dying and in the ways in which they are governed to be accepted as truths, constituting the body of palliative care knowledge as another form of managing death. The origins of this care philosophy are described in the United Kingdom, in the 1960's, when the physician, nurse and social worker Cicely Saunders created the St. Christopher Hospice in Londen. ${ }^{2}$ The creation of this hospice is commonly linked with the birth of palliative care. Cicely, in the intent to organize a body of knowledge focused on humanized care delivery during the period that precedes death, supposedly created the hospice philosophy, a therapeutic proposal that did not emerge to replace technical biomedical care, but was associated with this model. ${ }^{5}$ This rupture between "modern death" and "post-modern death" was not aimed at releasing the subjects from a silent and hidden death, but at inserting it into a new discourse order, submitted to other power and knowledge devices. ${ }^{3}$

\section{THE HERMENEUTICS OF THE RESEARCH}

To answer our objective, we undertook a textual analysis, related to the field of cultural studies, particularly Foucault's post-structuralist branch. To use Foucault, we admit that we cannot formulate concepts to achieve pre-existing and hidden truths, awaiting their discovery. Hence, we use the author to operate on documents and question the chain of events in certain spaces, linked with certain histories. ${ }^{4}$

Textual analyses contribute to understand phenomena and rules that govern the production of discourses in a given age, showing the different meanings that are linked in the subjects' projection. This type of analysis treats the spaces of the contemporaneous world as producers of pedagogies. ${ }^{10}$ Therefore, we read the WHO manual on palliative care, which is part of the series Cancer control: knowledge into action: WHO guide for effective programmes. This manual, published in 2007, is available in English on the WHO website. For the purpose of the analyses, the guide had to be translated into Portuguese. This translation was elaborated by a Bachelor in languages/English and validated by a health professional who mastered the language. As the authors of this study, we take full responsibility for the translations developed.

In that sense, we proposed to use the instruments made available in the reference framework to reflect on and move between the statements in the manual, in order to develop an interested reading of the texts, that is, "[...] this is about knowing what we can use and what we can dispose of, pass over or leave aside" ${ }^{6: 17}$ Therefore, we use some tools and theoretic proposals of Michel Foucault, which permitted this form of thought, reflection and analysis.

\section{PUTTING IN PRACTICE SAFETY DEVICES}

One can consider the introduction to statistical and epidemiological knowledge as the main responsible for the rationality that allows us to talk about populations and build knowledge about it. 
When we start to translate events, the bodies and their actions into figures, it became possible to control the population and govern and regulate processes that affect it. Thus, knowledge about individuals' disease and death processes, for example, permits the definition of standards aimed at governing to invest in life and try and minimize the risks that affect the population. Therefore, new knowledge needs to be invented and safety devices need to be put in practice, in view of the need to know and teach the population to make it manageable. But how can this be done? Guidelines, folders and manuals can be important artifacts to try and educate subjects, so that they become more easily manageable and, consequently, protect their lives.

When opening the first pages of the WHO palliative care manual, we are confronted with the current panorama and probable future epidemiological perspectives on cancer around the world. After reading the statements, we are gradually subjectified to think about how oncologic diseases have been threatening and putting the lives of all of us at risk. In that sense, as early as on the first pages, the manuals summons us to embark on its reading, perhaps to incorporate conducts that can help us to interfere in the cancer epidemic, trying to protect both our lives and those of the population in general, like in the following excerpt from the manual: "Cancer is largely avoidable. Many types of cancer can be prevented. Others can be detected in early stages, treated and cured. Even in an advanced stage, the pain can be reduced, the progression of the cancer slowed down and the patients and their families helped to better cope with the disease" ${ }^{11: i i i}$

In the following excerpts, we continue to be subjectified in the statements about the global cancer problem. This fact makes us think about how the manual challenges its readers: Did you know that cancer is the main cause of death around the world? That 7.6 million people died of cancer in 2005? That an estimated 84 million people will die of cancer in the next ten years, and that $70 \%$ of these deaths happen and will happen in developing countries? Then we ask ourselves: but what can we do to revert this scenario and minimize these risks within our territory, for our population?

That is where the role of the WHO manual comes up. When we study the manual, we feel responsible for using the tools highlighted there to change the global picture of cancer. While reading the guide, we are held accountable for the early prevention, cure and diagnosis of cancer. In case of "errors' in the course of these phases, we can also live with the disease better through palliative care. One can observe in the following excerpt how these data are presented, so as to subjectify and objectify us, guiding our conducts: "Cancer is the main cause of death around the world. WHO estimates that 7.6 million people died of cancer in 2005 and that 84 million will die in the next 10 years if no actions are put in practice [our italics]. More than $70 \%$ of all deaths caused by cancer happen in poor and developing countries, where the resources available for prevention, diagnosis and treatment are limited or do not exist". 11:iii

When we look at and work with statistical data, it seems that situations gain form that need to be changed. In dealing with figures, in most cases, comparative pictures can be established and targets can be set. In a society in which safety devices rule, there is an avalanche of statistical data, as numerical knowledge makes efforts to cope with the future, that is, to try and foresee the future. If events could not be measured this way, directing actions, planning results and setting objectives would be practically impossible as, in order to govern a population, certain traits need to be knowledgeable and calculable. ${ }^{12}$ The series of WHO manuals, focused on cancer control around the world, addresses this disease as a "global public health problem", an epidemic around the world, that is, a disease that goes beyond the maximum levels of expected cases, calls for solutions, for actions that can reduce the population's risk of illness and the danger of death as a result of this illness. ${ }^{11: \mathrm{V}}$ The fact that we can calculate the possibility of an event does not mean that it can be prevented, as what we calculate are but probabilities that, although calculable, do not grant the certainty that the danger will be avoided or not. ${ }^{1}$

In part of his work, Foucault discusses issues related to epidemics. According to the author, when considering epidemics, we are generally referring to rates that exceed expected levels for the occurrence of a certain situation and that, therefore, are unforeseen. ${ }^{13}$ Thus, we enforce governmental action to manage these situations, as well as interventions to normalize this event. Hence, the safety devices intend to be regulatory, acting on epidemic issues without any claim on solving all social problems, but reducing the possible damage they can cause.

Thus, morbidity and mortality rates due to oncologic diseases need to be kept at acceptable levels, levels that do not threaten the survival of 
the human species. These acceptable levels would be what Foucault called optimal averages, that is, rates that continue at social and economically acceptable levels, permitting the proper functioning of society. ${ }^{13}$

As from 2005, WHO outlined a bio-political strategy to prevent, fight and control high cancer rates around the world. As a part of this strategy, tactics were articulated to permit an action plan. These tactics include planning guides which, through the available resources and interaction with other chronic disease control programs, it would be possible to plan cancer control; prevention, focusing on the implementation of programs to control for avoidable risk factors of cancer; early detection, aimed at executing programs to detect the main types of cancer that can be diagnosed and screened in the initial stage; diagnosis and treatment, with emphasis on the implementation of programs to diagnose and treat curable cancers; palliative care, aimed at putting in practice community-based programs; policy and advocacy, focused on the development of policies to implement cancer control programs.

We can observe that the palliative care tactic is not WHO's main strategic focus, which is centered on the treatment and cure of cancer. Palliative care emerges as a bio-policy to deal with that part of the population that will be left at the margin of correction rates and which a life-regulating policy is also needed as, even if optimal average cancer treatment and cure rates are achieved, there will always be a part of the population to complete the morbidity and mortality statistics.

Therefore, one needs to know: where are the populations that need policies to normalize their morbidity and mortality rates due to cancer? The first pages of the manual already answer that question: WHO's cancer control strategy is mainly focused on developing countries, where the statistics need to be corrected and framed to preestablished standards - it is highlighted that the standards issued by WHO, the organization that is considered the authority to define these targets, could be considered as pre-established. But how can be know what are the optimal average rates of illness and death caused by cancer? We will only be able to define what lies within a security margin when two elements can be compared, in this case developed and developing countries. When these two are confronted, one can define what would be the "ideal" and what lies beyond that margin and needs normalization. Then, gaps are left for normalization policies to complete, which should respond to the population's processes. We start to perceive here that these policies, in the mind of a society in which safety devices are functioning, already depart from the premise that part of the population will not be normalized and, consequently, will get ill and die of cancer, as the safety will try to "create an environment in function of events or series of events or possible elements, series that will need to the regulated in a multivalent and transformable context" ${ }^{\prime 13: 27}$ To put these teachings in practice, the manual uses palliative care experiences that worked in developed countries, which should be followed, as these are actions authorized by WHO.

At the start of the palliative care manual, the collection, which includes six cancer control guides, is presented in an orderly manner: planning, prevention, early detection, diagnosis and treatment, palliative care and policies and defenses. In the presentation texts, expressions like "effectively planning general cancer control", "controlling the main avoidable risk factors", "implementing an effective program for the purpose of cancer control" are emphasized. 11:IV As observed, these policies are focused on managing the risks that can haunt the population. These risks need to be kept under control, under surveillance, so as to study them, read them, interpret them, get to know and govern them, considering that, as risks, they can still be reverted, as they are part of the probabilistic order of the event.

Next, we can observe the images on the front page of the six manuals (Figure 1), so as to try and reflect on and understand how they summon and subjectify us, including us in the discursive order of the cancer control bio-policy. About these visible statements, we could consider that "[...] we will tend to believe much more in what we see than in what we hear [...]. Images are much more 'real' than printed or spoken words. The histories they tell hide who tells them [...]. Differently from human intermediaries, the cameras 'do not lie', 'tell the truth' (or at least that's what we have been trained to believe) [...] When we are confronted with a photographical, electronically obtained image, nothing seems to come between us and the reality; nothing that can capture or distract our look. 'First seeing then believing' means 'I'll believe it when I see it', but also 'I'll believe in what I see'" .1:29-30 


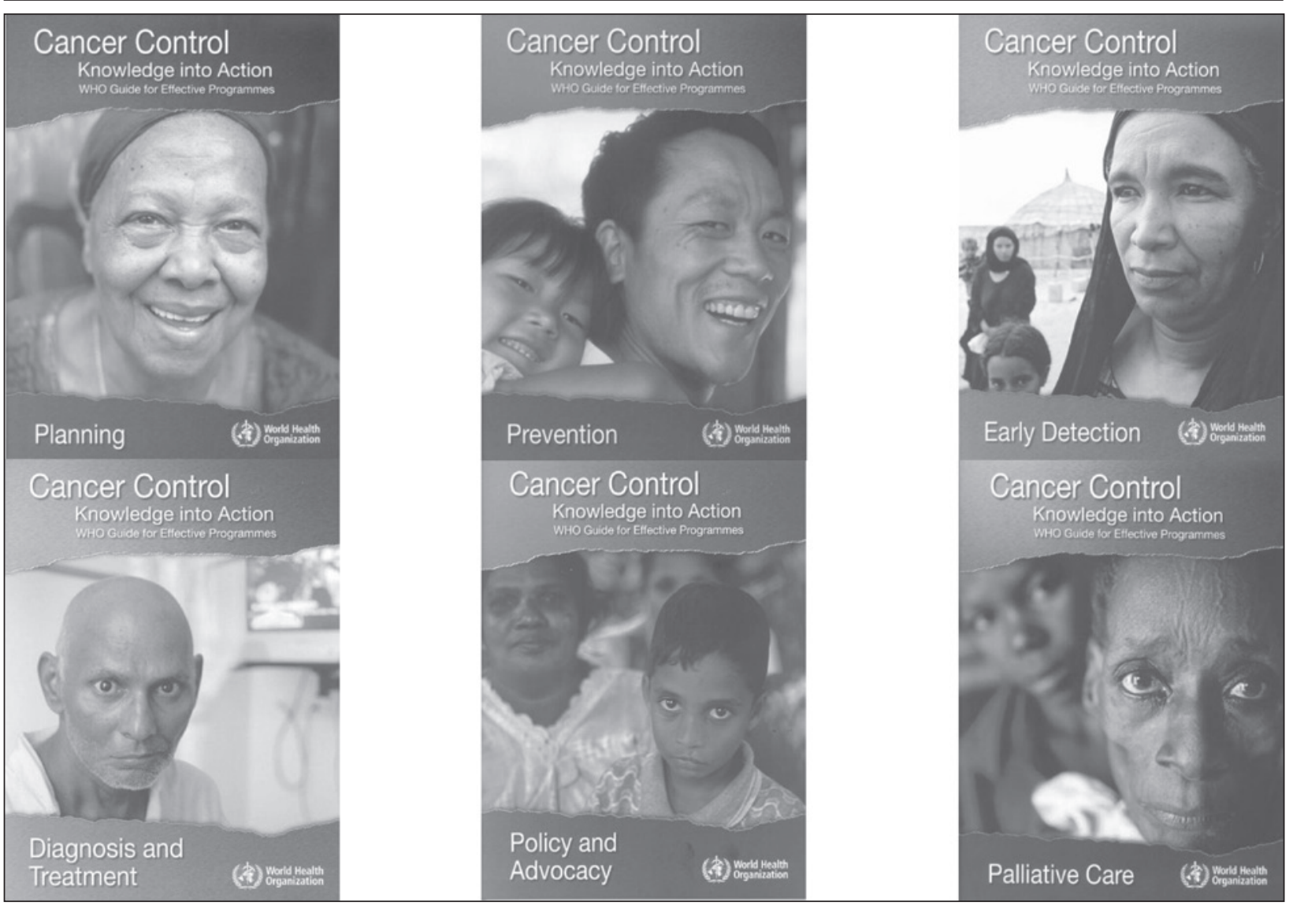

Figure 1 - Front pages of the WHO series of manuals "Cancer control" - planning, prevention, early detection, diagnosis and treatment, palliative care and policy and advocacy ${ }^{11}$

In a first and rapid look at these images, we could notice that they remit to poverty, as the people are wearing simple clothing, the backgrounds are not very sophisticated and, in one of the images, we can also see a straw shack. Perhaps this poverty, associated with the fact that the people who illustrate the pictures are of black, Asian or even Muslim origins, makes us think that these policies are focused on poor and developing countries, as the manual highlights. Therefore, in these locations, the optimal averages rates of illness and death due to cancer need to be sought and achieved, as statistics in these countries remain far higher than what $\mathrm{WHO}$ accepts and describes as desirable. These images intend to represent these countries as, when looking at them, we think of Asian, African and South American countries, showing that their populations are marginalized in terms of risk of illness and death due to cancer. Also, when considering the titles of the six manuals and the images on their front pages, we could think about how cancer affects an individual in different stages of the disease, provoking changes in their body, in their family and social context.
In the planning and prevention guides, we see happy and smiling people, possibly showing a structured and healthy family, visualized through the image of the child who hugs his father. We could also consider the three human development phases represented in a healthy manner: the child, the adult and the elderly. Thus, these images seem to show that, with planning and prevention, the biological lifecycle will not be interrupted early.

When planning and prevention did not have the desired effects, we move on to another moment: that of early detection. The image on this manual carries a sense of mystery. We were unable to perceive whether the people shown carry signs of joy or sadness, the clothing is sober and there seems to be some distancing between the family and the elder women, who is highlighted in the picture and may be the family matriarch. This woman could be the person affected by the disease. The same image could expressed the silent nature of cancer, as one cannot perceive physical degradation in the woman illustrating the picture, demonstrating that, initially, the disease could install itself without any signs. 
In the image that illustrates the diagnosis and treatment guide, then, the oncologic disease has already established itself. The person on the picture seems solitary in a place that could be the hospital, with light-colored walls, a television on the wall, besides the white clothing covering the patient's body. The fact that no family is present with the man in the picture remits to issues of hospitalization and the treatment practiced in hospitals, places with strict disciplinary regimes, considered capable of separating the patients and their families. The man focused on in the image is thin, his beard is long, and we can observe baldness, a common characteristic in people going through chemotherapy.

Next in our analysis of the images is the scene illustrating the palliative care guide. In this image, a person is focused on with an apparently established and quite advanced oncologic disease. This fact is shown through the physical degradation of the body, the bags under the eyes and the deep eyes, the loss of subcutaneous tissue in the face and the severe weight loss, which even shows the blood vessels on the forehead. This deteriorated body image and the connotation of sadness approach us to death. The family, in the figure of the body in the background, returns to the image, as the family's life would also be focused on in this care modality, as well as providing a good death to the patient and to the people around him.

In the final image, on the guide about policy and advocacy, differently from all others, the main focus is on a child, instead of an adult or a family. The child could refer to hope and the future. This picture seems to contain many people, even if only three are visible. This makes us think that these people could represent the population, which needs something to be done in its defense, the planning and implementation of policies to manage their lives and the processes occurring in it.

The sight of the entire collection gives the impression that there are many alternatives to reduce disease and death due to cancer: $1^{\circ}$ ) Plan programs for cancer control appropriately; $2^{\circ}$ ) Implement programs to control the risk factors for the appearance of cancer; $3^{\circ}$ ) Detect the appearance of cancer rapidly; and $4^{\circ}$ ) Diagnose and treat the oncologic disease. So far, we had four alternatives aimed at "making people live". With each step, disease and death become more present. While the first two steps refer to policies focused on the risks affecting the population, the following two try to fight the danger, as the risks can no longer be managed, but the haunting enemy can be eliminated.

There are four chances to make the population live, provided that it is appropriately managed for all people to take care of themselves, undergo routines tests and plan their lives. In short, this way, when the enemy is present, it can be fought. Each time one of the steps proposed in the manual is unable to respond to the threats the disease poses, we depart for the next steps, until all situations forecasted can be fit into the cancer control policy. When treatment and cure are no longer possible, step five comes up: mitigate the suffering of those who can no longer be cured. "Give more life to the days of these people than days to life", as Cicely Saunders recommended: implement palliative care.

When we analyze these governance strategies based on a safety device, what appears are not the individuals and their bodies, like in the device of discipline, but the set of living individuals that constitutes the human species, that is, "the set of mechanisms through which that what constitutes the human species' fundamental biological characteristics can be included into a policy, a political strategy, a general power strategy". 13:3

To govern the members of a population well and protect them against the risk of illness due to cancer, efforts need to be made to keep the morbidity and mortality rates due to cancer within the optimal average levels. These statistics need to enhance the development of the population and keep its members and processes under control, which regulate the activities and lives of these individuals, which establish what is permitted and prohibited, how many can die and those whom we need to "make live". Thus, developed countries are able to maintain the levels of disease and death by cancer within the optimal rates through prevention, early diagnosis and appropriate treatment. In developing countries, on the other hand, these rates continue higher than expected, demanding policies to reduce and normalize them.

A palliative care policy is necessary to capture all of those individuals who escaped from other political actions that were aimed at life, aimed at "making people live", that is, at cure. What we can do now is to let these people die, but while offering quality of life in the time they have left. Thus, the bio-power comes into account so as not to allow anyone to escape from its actions, whether focused on the preservation of life or on quality of life in death. We cannot forget either that 
death is a form of regulating the species, of guaranteeing survival as, on the opposite, there might be overpopulation, and chaos would be installed. Governing would mean to maintain what is bearable, it would not mean avoiding further deaths, but also, consequently, it would not mean making everybody live. How could one live in a world in which nobody died? That is why we work with optimal event rates, as a minimal part of the population could be left at the margin. This mortality rates is expected, calculated and necessary; these deaths would be the authorized deaths. ${ }^{13}$

In the safety society, concerns are focused on the set of individuals, and not on each isolated case; this is not about solving all social problems, but about reducing the damage they caused, giving them medical treatment, bringing them down to acceptable levels. The focus is on collective action that ends up affecting the individual. Therefore, we work with statistics and epidemiology, as these data (in)form conducts and policies. The treatment of these data and the non-permission of their saturation turns them into objects of bio-political devices. And that is what helps to direct the actions and permits the invention of other knowledge to cope with what was left out, which apparently could have escaped from the web of bio-power.

\section{ABOUT THE MANAGEMENT OF THE MANUAL}

In this study, we proposed one possible form of reflecting on and problematizing the invention of the palliative care discipline, without making any claim on serving as a truth about the emergence of this discourse regimen. We were not concerned with making the statements articulated here seem improper or, who knows, distant from the people sustaining the palliative care discourse. Nevertheless, we do realize that this text affects the people who read it.

In this text, we aimed to think how the discourse about palliative care, as published in the WHO manual, articulates and (re)invents a new discipline, producing another rationality, building devices of truth that subjectify and govern us, serving as one of the tactics in a bio-political strategy that defends life. We have tried to problematize the body of palliative care knowledge as one of the artifacts included in a safety device intended at controlling cancer around the world.

We believe that WHO considers that the series of cancer control manuals should be focused on developing countries, with the presence of the poorest or lowest-income groups (in accordance with the same manual), which are supposed to be more exposed to the avoidable risk factors of cancer. As these groups exert less political influence, have less access to health services and generally have lower education levels, they would be in a weaker position for decision making on the protection and improvement of their own health. Hence, in these places, bio-policies would be needed to serve "in defense of society", managing the risks that affect these people and distancing possible sources of danger.

These WHO manuals, focused on cancer control around the world, would function as a system of expertise, aimed at educating, governing and subjectifying, so as to make life, the treatment and cure of cancer feasible. If this fact were not possible, alternatives would be indicated to try and solve the problem of small daily deaths, which would happen in the development course of a chronic illness, to the detriment of the big death that could not be corrected. Hence, palliative care emerges as an alternative, proposed to consider care delivery to patients beyond the therapeutic possibility of cure in a different manner, inventing another form of care that tries to define another normalization code that passes through the filter of science. ${ }^{14}$

\section{REFERENCES}

1. Bauman Z. Medo líquido. Rio de Janeiro (RJ): Jorge Zahar; 2008.

2. Lazzarato M. As revoluções do capitalismo: a política no império. Rio de Janeiro (RJ): Civilização Brasileira; 2006.

3. Revel J. Michel Foucault: conceitos essenciais. São Carlos (SP): Claraluz; 2005.

4. Castro E. El vocabulario de Michel Foucault. Buenos Aires (AR): Universidad Nacional de Quilmes; 2004.

5. Foucault M. A ordem do discurso: aula inaugural no Collège de France, pronunciada em 2 de dezembro de 1970. 13 ${ }^{\text {a }}$ ed. São Paulo (SP): Edições Loyola; 2006.

6. Veiga-Neto A. Foucault e a educação. $2^{\mathrm{a}}$ ed. Belo Horizonte (MG): Autêntica; 2007.

7. Foucault M. Microfísica do poder. $21^{\mathrm{a}}$ ed. Rio de Janeiro (RJ): Graal; 2005.

8. Sontag S. Doença como metáfora: AIDS e suas metáforas. São Paulo (SP): Companhia das Letras; 2007.

9. Bauman Z. Modernidade e ambivalência. Rio de Janeiro (RJ): Jorge Zahar; 1999.

10. Portocarrero V. Os limites da vida: da biopolítica aos cuidados de si. In: Albuquerque Júnior DM, Veiga- 
Neto A, Souza Filho A, organizadores. Cartografias de Foucault. Belo Horizonte (MG): Autêntica; 2008.

11. World Health Organization. Cancer control: knowledge into action: WHO guide for effective programmes: Palliative Care. Geneva: World Health Organization; 2007. [acesso 2009 Fev 18]. Disponível em: http://www.who.int/cancer/media/FINALPalliativeCareModule.pdf

12. Rose N. Governando a alma: a formação do eu privado. In: Silva TT, organizador. Liberdades
Reguladas: a pedagogia construtivista e outras formas de governo do eu. Petrópolis (RJ): Vozes; 1998.

13. Foucault M. Segurança, território, população: curso dado no Collège de France (1977-1978). São Paulo (SP): Martins Fontes; 2008.

14. Niemeyer F, Silva KS, Kruse MHL. Diretrizes curriculares de enfermagem: governando corpos de enfermeiras. Texto Contexto Enferm. 2010 OutDez;19(4):767-73. 